Original investigation

\title{
Craniodental and forelimb specializations for digging in the South American subterranean rodent Ctenomys (Hystricomorpha, Ctenomyidae)
}

\author{
Cecilia C. Morgan*, Diego H. Verzi, A. Itatí Olivares, E. Carolina Vieytes \\ Sección Mastozoología, División Zoología Vertebrados, Museo de La Plata, CONICET, Paseo del Bosque s/n, CP 1900 La Plata, Buenos Aires, Argentina
}

\section{A R T I C L E I N F O}

\section{Article history:}

Received 23 May 2017

Accepted 24 July 2017

Handled by Vera Weisbecker

Available online 26 July 2017

\section{Keywords:}

Incisor enamel

Rodentia

Scratch-digging

Skeletal morphometrics

Tooth-digging

\begin{abstract}
A B S T R A C T
We explored the distribution of tooth- and scratch-digging specializations in species of the subterranean rodent Ctenomys (tuco-tucos) from diverse environments and representing different clades. Principal component analysis of craniodental and postcranial indexes with functional relevance showed that specializations for tooth-digging on one hand, and scratch- digging on the other, formed two uncorrelated groups of variables; functionally significant enamel traits varied concurrently with the tooth-digging specialization axis. Species occupied all sectors of the morphospace showing that craniodental and forelimb specializations have not been mutually exclusive in the evolution of the genus.
\end{abstract}

@ 2017 Deutsche Gesellschaft für Säugetierkunde. Published by Elsevier GmbH. All rights reserved.

\section{Introduction}

Morphological specializations for digging and subterranean habits have evolved independently in various rodent lineages around the world, and have long appealed to biologists interested in morphological evolution. Among living South American hystricomorph rodents, the most specialized underground dwellers occur in the Octodontoidea and include the coruro Spalacopus cyanus (Octodontidae; Honeycutt et al., 2003) and the tuco-tucos of the genus Ctenomys (Ctenomyidae; Lessa et al., 2008; Reig, 1970). Most of the Octodontoidea lineages have fossorial habits and build complex burrows with no substantial morphological specialization (Lessa et al., 2008). In contrast, all species of Ctenomys are subterranean and have some degree of digging specialization (Lessa et al., 2008; Morgan and Verzi, 2006; Vassallo, 1998; Verzi and Olivares, 2006). As defined in Lessa et al. (2008), fossorial species spend a substantial fraction of their lives outside their burrows, while subterranean ones perform most activities underground. Ctenomys includes nearly 65 living species distributed throughout South America in varied habitats with diverse soil and vegetational char-

\footnotetext{
* Corresponding author.

E-mail addresses: cmorgan@fcnym.unlp.edu.ar (C.C. Morgan), dverzi@fcnym.unlp.edu.ar (D.H. Verzi), iolivares@fcnym.unlp.edu.ar (A.I. Olivares), cvieytes@fcnym.unlp.edu.ar (E.C. Vieytes).
}

acteristics (Bidau, 2015; Cook et al., 2000; Freitas, 2016; Reig et al., 1990; Woods and Kilpatrick, 2005). This genus is the only living representative of Ctenomyidae, a family with several extinct genera that encompass considerable disparity associated to the evolution of different degrees of adaptation to life underground (fossorial to subterranean) and digging strategies (scratch- and tooth-digging) at least since the late Pliocene (Fernández et al., 2000; Lessa, 1993; Quintana, 1994; Reig et al., 1990; Reig and Quintana, 1992; Verzi, 2008; Verzi et al., 2010a). In this context, tuco-tucos have been characterized as scratch-diggers that secondarily use their incisors for burrowing (tooth-digging) according to substrate requirements (Ubilla and Altuna, 1990; Camin et al., 1995; De Santis et al., 1998; Giannoni et al., 1996; Lessa, 1993; Lessa et al., 2008; Mora et al., 2003; Vassallo, 1998).

The study of specialized skeletal traits associated to different digging modes in rodents has been heterogeneous in terms of amplitude and range of samples. For dual-mode diggers, a combined approach is particularly interesting to avoid misleading assessments of digging specialization (Lessa, 1990). However, most works have focused on either craniodental or postcranial elements, and to a lesser extent, some have addressed both simultaneously (Hopkins and Davis, 2009; Lagaria and Youlatos, 2006; Lessa and Stein, 1992; Lessa and Thaeler, 1989; Lessa et al., 2008; Marcy et al., 2016; Morgan, 2009a; Samuels and Van Valkenburgh, 2009). For Ctenomys, previous analyses have focused on only few species (Vassallo, 1998) or partial arrays of traits (cranio-dental: e.g. 
Table 1

Craniodental, forelimb and enamel variables used in this study. References are given for original source of morphofunctional indexes.

\begin{tabular}{|c|c|}
\hline Variables & Definition, morphofunctional significance \\
\hline Amc & $\begin{array}{l}\text { Concavity of external auditory meatus (maximum distance between anteroexternal margin of external auditory meatus and posteriormost } \\
\text { point of concavity). This variable estimates the fit of the mandibular condyle in the postglenoid joint area (Verzi and Olivares, 2006). }\end{array}$ \\
\hline $\mathrm{Bl}$ & Basilar length \\
\hline Dab & $\begin{array}{l}\text { Anterior depth of auditory bulla (depth of auditory bulla in front of external auditory meatus, from dorsal contact with } \\
\text { squamosal-alisphenoid to ventral margin). Estimates the constraint imposed by the bulla on gape (Verzi and Olivares, 2006). }\end{array}$ \\
\hline Pc & $\begin{array}{l}\text { Width of base of postcondylean process. This variable estimates the fit of the mandibular condyle in the postglenoid joint area (Verzi and } \\
\text { Olivares, 2006). }\end{array}$ \\
\hline Pgw & $\begin{array}{l}\text { Width of postglenoid fossa (measured at origin of the posterior apophysis of the squamosal). This variable estimates the fit of the } \\
\text { mandibular condyle in the postglenoid joint area (Verzi and Olivares, 2006). }\end{array}$ \\
\hline Ib & $\begin{array}{l}\text { Distance between anterior margin of mandibular foramen ( } \mathrm{mf} \text { ) and extreme tip of condyle. Estimates depth of the insertion of the lower } \\
\text { incisor (Verzi and Olivares, 2006). }\end{array}$ \\
\hline Proc & Procumbency of upper incisors (in degrees). Related to angle of attack to soil during tooth-digging (Reig et al. 1965). \\
\hline DSN & $\begin{array}{l}\text { Relative depth of great scapular notch (DSN = Dsn/Tls). Dsn, depth of great scapular notch (maximum distance between scapular blade } \\
\text { and scapular spine); Tls, total length of scapula (from margin of glenoid fossa to intersection between scapular spine base and vertebral } \\
\text { border of scapula). Estimates relative development of } m \text {. infraspinatus; also related to direction of action lines of trapezius and deltoid } \\
\text { muscles (Morgan, 2009a). }\end{array}$ \\
\hline HUR & $\begin{array}{l}\text { Humeral robusticity }(\mathrm{HUR}=\mathrm{Hw} / \mathrm{Hl}) \text {. Hw, anteroposterior diameter at middle of humeral diaphysis; Hl, humeral length. Estimates bone } \\
\text { resistance, especially with regards to forces applied on the sagittal plane during scratch-digging (Elissamburu and Vizcaíno, 2004; } \\
\text { Hildebrand, 1985). }\end{array}$ \\
\hline RWE & $\begin{array}{l}\text { Relative width of distal epiphysis at epicondyles (RWE =Ew/Hl). Ew, maximum width at humeral epicondyles; Hl, humeral length. } \\
\text { Estimates development of hand flexor muscles (Hildebrand, 1985). }\end{array}$ \\
\hline RDO & $\begin{array}{l}\text { Relative development of olecranon }(\mathrm{RDO}=\mathrm{Ol} / \mathrm{Ul}) \text {. Ol, olecranon length; Ul, ulnar length. Estimates mechanical advantage of } m \text {. triceps } \\
\text { brachii (internal lever arm); also estimates available surface for attachment of hand flexor and extensor muscles (Hildebrand, 1985). }\end{array}$ \\
\hline EI & $\begin{array}{l}\text { External index }(\mathrm{EI}=\text { PET/ET). PET, portion externa thickness [radial enamel }(\mathrm{RE})+\text { prismless enamel }(\text { PLEX)]; ET, total enamel thickness. } \\
\text { Higher EI increases resistance to abrasion (Boyde and Fortelius, 1986; Rensberger and Koenigswald, 1980), as does a thick PLEX (Flynn } \\
\text { et al., 1987). }\end{array}$ \\
\hline HSBi & $\begin{array}{l}\text { Hunter-Schreger band inclination, measured as the angle between the HSB and a line perpendicular to the enamel-dentine junction. } \\
\text { Increasing inclination reinforces resistance to fracture spread (Koenigswald et al., 1987; Martin, 1999; Pfretzschner, 1988; Rensberger, } \\
\text { 1997). }\end{array}$ \\
\hline
\end{tabular}

Álvarez et al., 2015; Becerra et al., 2012; Borges et al., 2016; Mora et al., 2003; Verzi and Olivares, 2006; Vieytes et al., 2007; postcranial: e.g. Echeverría et al., 2014; Morgan, 2009b, 2015; Morgan and Álvarez, 2013; Morgan and Verzi, 2006; Steiner-Souza et al., 2010). In this study, we revise craniodental and postcranial traits linked to digging ability in species representing different major clades within Ctenomys (Mascheretti et al., 2001; Parada et al., 2011). We do not focus on the phylogenetic pathways of acquisition of such traits, but rather on exploring how tooth- and scratch-digging specializations are combined and distributed through the variation of living Ctenomys. Detected patterns are discussed and compared with those described for other digging rodents.

\section{Material and methods}

We analyzed craniodental and postcranial morphology in 88 specimens of 18 living species of Ctenomys (detailed information in Supplementary material 1). The sample includes species that occupy different environments through diverse areas of South America and spanning major Ctenomys clades (i.e. groups 'mendocinus', 'frater', 'boliviensis', 'talarum', 'opimus', 'Corrientes' and the basal species C. leucodon; Mascheretti et al., 2001; Parada et al., 2011). Seven craniodental measurements (Fig. 1) with morphofunctional significance were taken following Verzi and Olivares (2006); for analysis, raw values (abbreviations with capitalized first letter) were divided by basilar length to obtain standardised variables (abbreviations in all capitals), except procumbency, which is an angular measurement. To analyze the postcranial skeleton, four indexes (abbreviations in all capitals) were built from seven measurements (Fig. 1), following Hildebrand (1985), Elissamburu and Vizcaíno (2004) and Morgan (2015). Table 1 presents the definition and functional interpretation of these craniodental and forelimb measurements and indexes. $\mathrm{Bl}, \mathrm{Ib}$ and $\mathrm{Pc}$, and all postcranial measurements were taken using digital calipers $(0.01 \mathrm{~mm})$. Proc was measured with a protractor on camera lucida drawings (after Reig et al., 1965). The remaining cranial and mandibular measurements were obtained using a reticule eyepiece in a Leica MS5 stereo- microscope. The morphometric dataset was explored via Principal Components Analysis (PCA) of a correlation matrix of mean values for each species. Missing data (9.3\%) were estimated by the multiple- imputation method using NORM 2.03 (Schafer, 1997). Possible relationship between the indexes used in this study and body mass (evolutionary or interspecific allometry; Cock, 1966; Gould, 1966; Klingenberg and Zimmermann, 1992) was explored by means of lineal regressions of the log-10 transformed species means onto a size estimator (DP4- M2 length) using Model II (standard major axis) in the software package SMATR (Warton et al., 2006). Enamel microstructure was analyzed in three species that span the range of tooth-digging adaptation in the genus: $C$. australis, C. talarum, and Ctenomys sp. 'perucho' (see Vassallo, 1998; Verzi and Olivares, 2006, Vieytes et al., 2007). The incisors were embedded in artificial resin and cut in longitudinal sections from their flat medial surface. Each tooth was ground using sandpaper and 1000 -grit powdered silicon carbide, and etched for 4-5 s with $10 \%$ hydrochloric acid to accentuate topographic detail (Flynn and Wahlert, 1978). After rinsing and drying, samples were sputtercoated with gold. Photographs of sections were taken under a Jeol JSM 6360 LV scanning electron microscope (SEM). Table 1 presents the definitions of variables and indexes measured from the photographs (Flynn et al., 1987; Koenigswald, 1985; Korvenkontio, 1934; Wahlert and Koenigswald, 1985). The enamel samples are deposited in the Mammals collection of Museo de La Plata.

\section{Results}

\section{Allometry analyses}

Among craniodental indexes, only PGW and DAB showed a statistically significant correlation with size, while none of the postcranial indexes showed statistically significant correlation with the size estimator (Table 2). PGW showed strong positive allometry, while DAB was negatively allometric; in any case, both indexes had very low correlation with size. For regressions made using raw measurements, significant correlation with the size esti- 


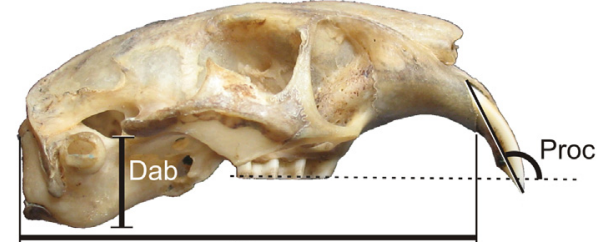

A)

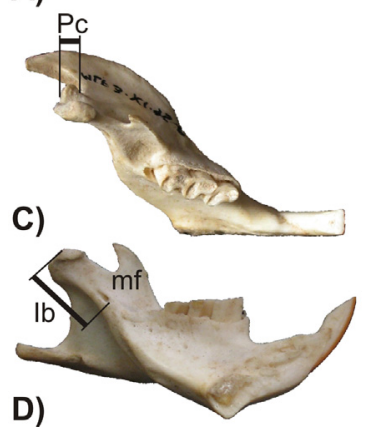

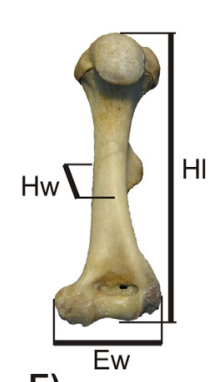

E)

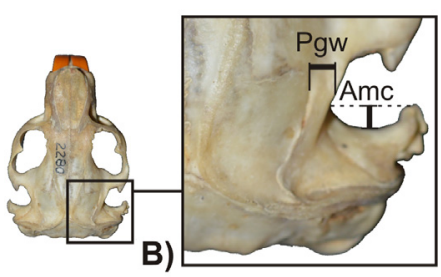

B)

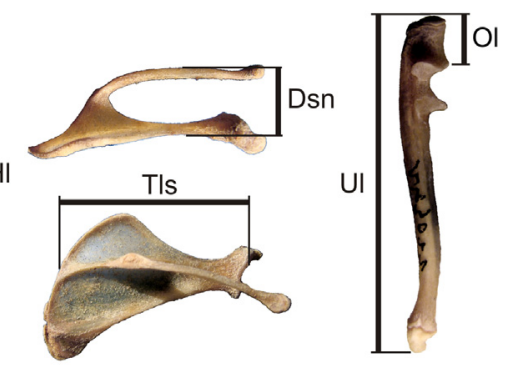

F)

G)

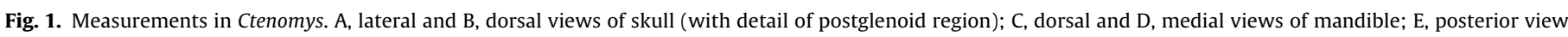

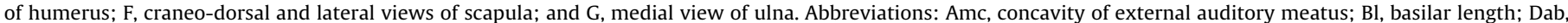

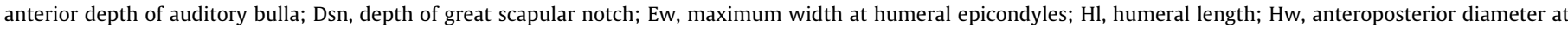

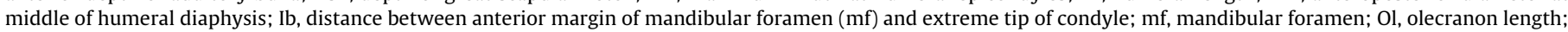
Proc, procumbency of upper incisors; Pc, width of base of postcondylean process; Pgw, width of postglenoid fossa; Tls, total length of scapula; Ul, ulnar length.

Table 2

Model II regression(SMA, standardised major axis) of cranial and postcranial indexes used in this work on DP4-M2 length (as proxy for size). Asterisk denotes significant regression $(\mathrm{p}<0.05)$; bold font denotes significant allometry. Abbreviations: $a$, intercept; $b$, slope; $r^{2}$, coefficient of determination.

\begin{tabular}{llll}
\hline Variables & $\mathrm{r}^{2}$ & $\mathrm{~b}(95 \%$ confidence interval $)$ & $\mathrm{a}$ \\
\hline AMC & 0.025 & $-3.28(-5.42$ to -1.98$)$ & 1.24 \\
DAB & $0.277^{*}$ & $-\mathbf{1 . 4 4}(-\mathbf{2 . 2 5}$ to $-\mathbf{0 . 9 3})$ & 0.59 \\
IB & 0.189 & $-1.95(-3.09$ to -1.23$)$ & 0.91 \\
PC & 0.053 & $-3.63(-5.96$ to 2.21$)$ & 1.87 \\
PGW & $0.359^{*}$ & $\mathbf{2 . 9 7}(\mathbf{1 . 9 6}-\mathbf{4 . 4 8})$ & -4.31 \\
Proc & 0.21 & $0.63(0.39-0.99)$ & 1.45 \\
DSN & 0.019 & $-0.59(-0.98$ to -0.36$)$ & 0.04 \\
HUR & 0.142 & $0.86(0.54-1.38)$ & -1.79 \\
RDO & 0.125 & $0.79(0.46-1.34)$ & -1.42 \\
RWE & 0.04 & $0.64(0.39-1.05)$ & -1.07 \\
\hline
\end{tabular}

Table 3

Factor loadings of variables for the first two PCs. Loadings $>0.7$ in bold.

\begin{tabular}{lll}
\hline Variables & PC 1 & PC 2 \\
\hline PC & $\mathbf{- 0 . 8 7}$ & 0.39 \\
IB & $-\mathbf{0 . 9 4}$ & 0.19 \\
PGW & $\mathbf{0 . 7 3}$ & 0.49 \\
AMC & $\mathbf{0 . 7 3}$ & -0.43 \\
DAB & $-\mathbf{0 . 8 5}$ & 0.24 \\
Proc & $\mathbf{0 . 8 7}$ & 0.02 \\
DSN & 0.45 & -0.64 \\
HUR & 0.52 & 0.68 \\
RWE & 0.45 & 0.69 \\
RDO & 0.34 & $\mathbf{0 . 8 2}$ \\
Eigenvalue & 4.96 & 2.68 \\
Total variance & $49.56 \%$ & $26.77 \%$ \\
\hline
\end{tabular}

mator was found only for Pgw among cranial variables, and for all postcranial variables (Supplementary Material 2).

\section{Principal component analysis}

The first two principal components (PC1 and PC2) summarized $76.33 \%$ of the variation in the sample (Fig. 2, Table 3). PC1 (49.56\% of explained variation) summarized mainly the variation of craniodental variables (Proc, IB, PGW, AMC, DAB, and PC). Positive scores
Table 4

Measurements and indexes of the upper incisor enamel of ctenomyids examined. EI, external index; ET, total enamel thickness; HSBi, Hunter- Schreger band inclination; PET, thickness of portio externa. EI, ET, PET in $\mu \mathrm{m}$; HSB in degrees. Values represent mean $\pm \mathrm{SD}$, or range in $\mathrm{HSBi}$.

\begin{tabular}{llllll}
\hline Species & ET & PET & EI & HSBi & n \\
\hline C. australis & $226.34 \pm 27.1$ & $31 \pm 3.46$ & $0.14 \pm 0.01$ & $30-40$ & 3 \\
C. talarum & $187.13 \pm 19.6$ & $31.5 \pm 2.88$ & $0.17 \pm 0.01$ & $30-45$ & 8 \\
Ctenomys sp. & 230 & 50 & 0.24 & $40-48$ & 1 \\
\multicolumn{1}{c}{ 'perucho' } & & & & & \\
\hline
\end{tabular}

on PC1 are associated to higher upper incisor procumbency (Proc) and depth of implantation of the lower incisor (IB), greater development of postglenoid fossa width (PGW), increase in concavity of the external auditory meatus (AMC), lesser development of the postcondyloid process (PC), and decrease in anterior depth of the bulla (DAB); these craniodental indexes are related to tooth- digging ability (Table 1 ). In turn, PC2 (26.77\% of explained variation) was highly correlated with morphological specializations of the scapula (DSN), humerus (HUR and RWE) and the forearm (RDO). Positive scores on PC2 were associated to higher development of the olecranon (RDO), greater width of the distal humeral epiphysis (RWE) and humeral robusticity (HUR), and lesser depth of the great scapular notch (DSN); these postcranial indexes are related to scratch-digging ability (Table 1 ).

In this morphospace, Ctenomys species were distributed in all four quadrants; those with stronger craniodental specializations (e.g. C. lewisi, C. leucodon, Ctenomys sp. 'perucho') were located at positive PC1 scores, while those with more marked forelimb specializations (e.g. C. frater, C. steinbachi, Ctenomys sp. "mármol"), at positive PC2 scores (Fig. 2). As expected from the allometric analyses of indexes (and even raw cranial measurements), their distribution was not related to size.

\section{Enamel microstructure}

Table 4 summarizes the measurements and indexes that characterize the enamel microstructure of incisors in three Ctenomys species with different digging modes. Further details of incisor enamel of the scratch-digger $C$. australis (Fig. 3A) and the occa- 


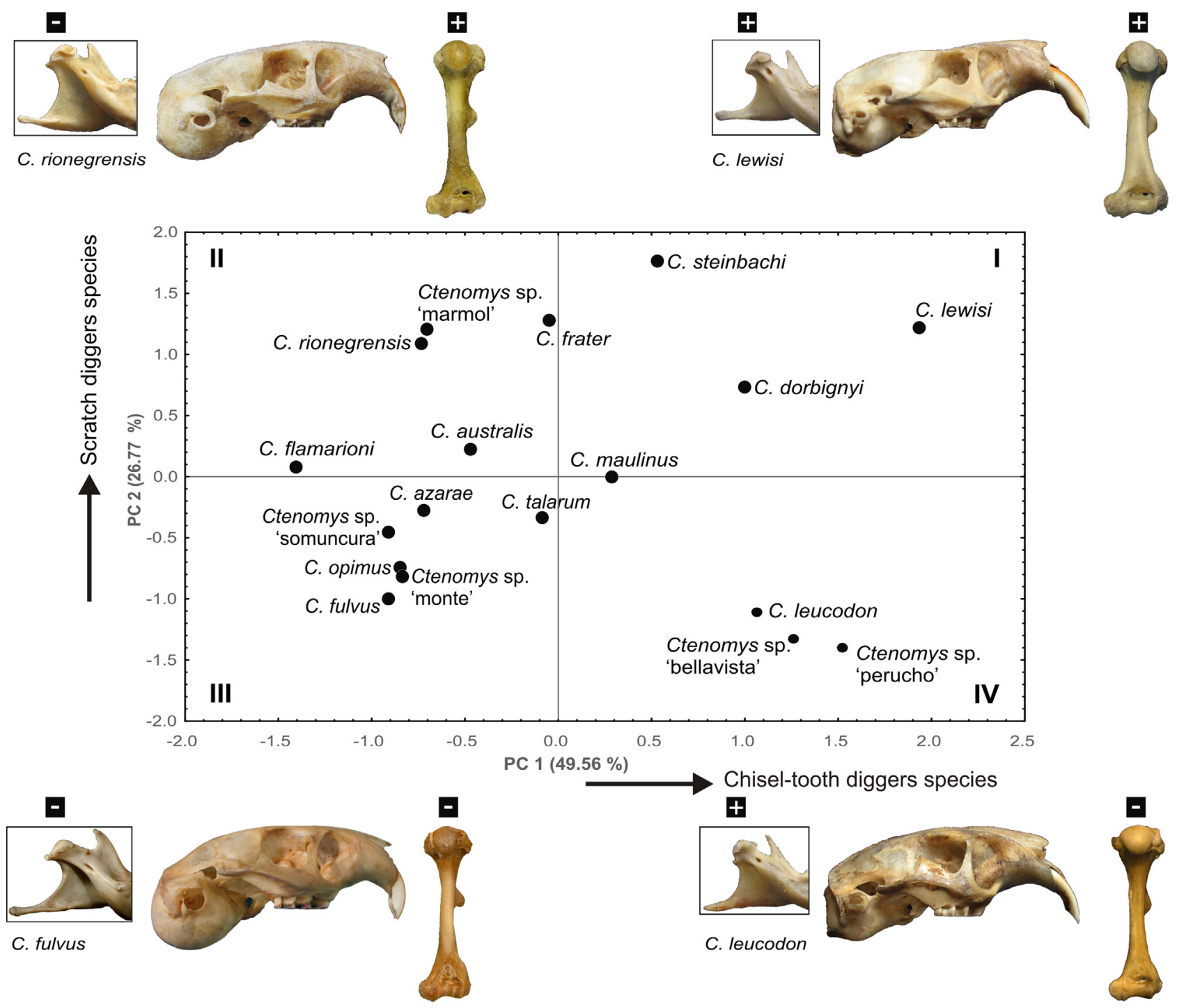

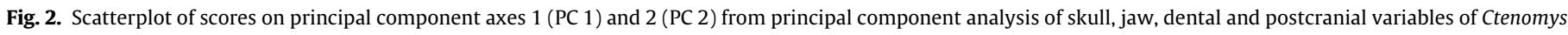

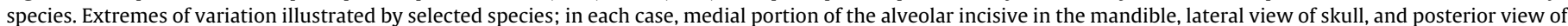
humerus is shown. I-IV: quadrants.

sional tooth-digger $C$. talarum (Fig. 3B) were published by Vieytes et al. (2007) . Ctenomys sp. 'perucho' (Fig. 3C) has a total enamel thickness (ET) of $230 \mu \mathrm{m}$ with a thick layer of radial enamel (RE: $24 \%$ of ET); the inclination of Hunter-Schreger bands (HSBi) is high, greater than $45^{\circ}$. Although the observed between-taxa disparity in enamel traits is low (as expected for an intrageneric comparison), Ctenomys sp. 'perucho' shows interesting differences in the studied traits: it has the highest values of HSBi, RE, External Index (EI) and portio externa thickness (PET).

\section{Discussion}

As mentioned above, when compared to epigean and fossorial non- specialized octodontoids, all species of Ctenomys exhibit some degree of craniodental and forelimb specialization, which has been described in a comprehensive literature (see literature cited in Álvarez et al., 2015 and Morgan, 2015). As primary scratch-diggers, they have robust arm bones with large crests and processes, and well-stabilized articulation surfaces (Echeverría et al., 2014; Morgan and Álvarez, 2013; Morgan and Verzi, 2006, 2011; Vassallo, 1998), traits that provide larger surface areas for muscle attachment and greater resistance to the forces gener- ated during digging, and occur in many scratch-digging mammals (Dubost, 1968; Hildebrand, 1985; Stein, 2000; Polly, 2007; Samuels and Van Valkenburgh, 2008). Similarly, many of their craniodental specializations, such as relatively large skull, strong rostrum, robust and generally flaring zygomatic arches, well developed nuchal crest, relatively short and deep mandible, and strong, procumbent incisors with deep implantation also occur in other tooth-digging rodents (Dubost, 1968; Gomes Rodrigues et al., 2016; Hildebrand, 1985; Lessa, 1990, 1993; McIntosh and Cox, 2016; Nevo, 1979, 1999; Stein, 2000; Vieytes et al., 2007). Additionally, Ctenomys species have a specialized postglenoid joint morphology that stabilizes the jaw joint (Álvarez et al., 2015; Verzi and Olivares, 2006).

Beyond verifying the existence of these shared features, we explored the simultaneous distribution of craniodental and forelimb variation related to digging among Ctenomys species, as estimated by key traits (Table 1). Although variation of these traits was previously studied within the genus (see, for example, Borges et al., 2016; Mora et al., 2003; Morgan and Álvarez, 2013; Verzi and Olivares, 2006; Vassallo, 1998; Vieytes et al., 2007), it had not been examined in a concurrent analysis. Our results showed that specializations for tooth-digging on one hand, and scratch- digging on the other, formed two groups of variables that were distinctly uncor- 

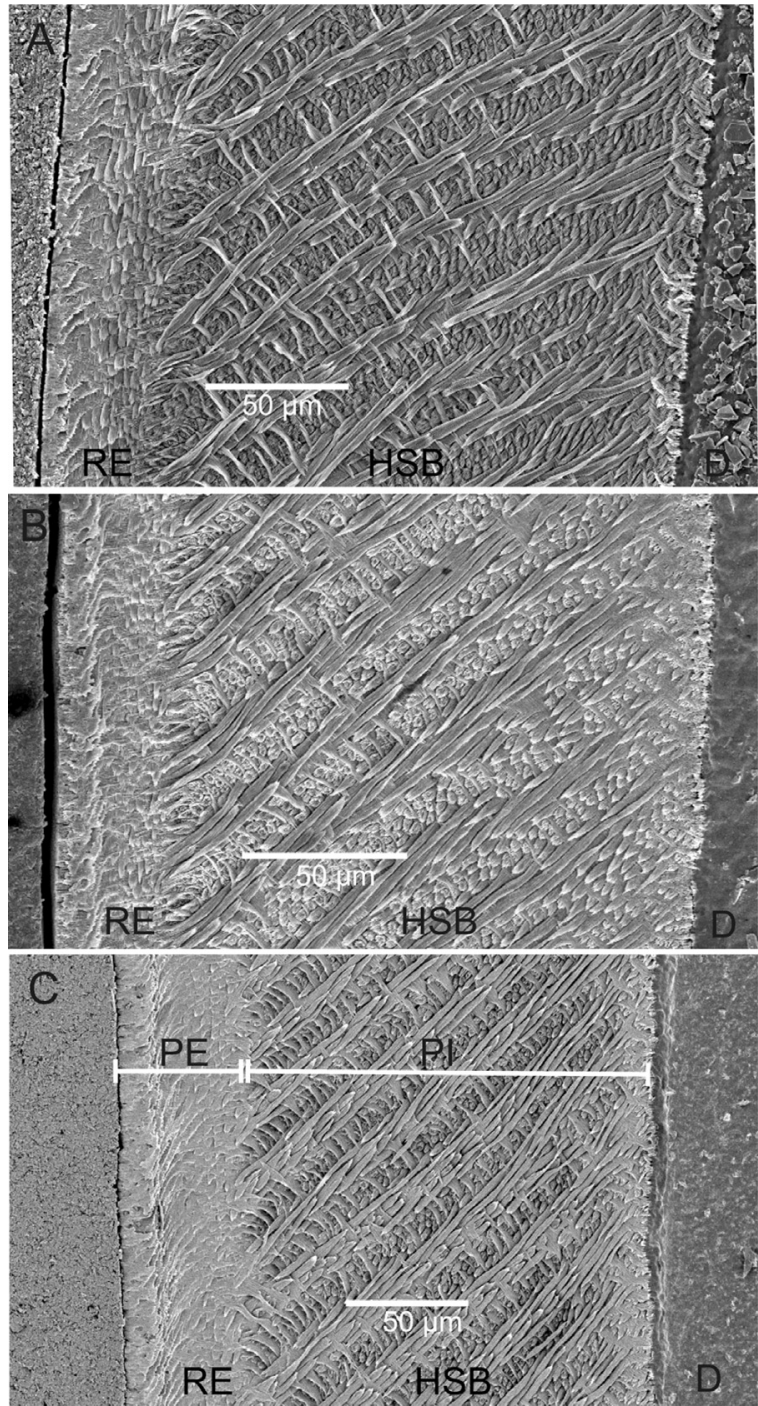

Fig. 3. SEM photographs of enamel microstructure of upper incisors (longitudinal sections, outer tooth surface at left, enamel-dentine junction at right, and occlusal tip down): A. Ctenomys australis; B. Ctenomys talarum; C. Ctenomys sp. 'perucho'. Abbreviations: D, dentine; HSB, Hunter-Schreger Bands; PE, portio externa; PI, portio interna; RE, radial enamel.

related. Thus, PC1 summarized tooth-digging specializations, with species positioned along this axis in agreement with the findings of Verzi and Olivares (2006). Furthermore, the enamel microstructure of one of the species highly specialized for tooth-digging, Ctenomys sp. 'perucho', presented high EI and greater HSBi (Table 1; Vieytes et al., 2007), while the primarily scratch-digger C. australis (Vassallo, 1998) showed lowest EI and HSBi values, and the occasionally tooth-digging C. talarum (Vassallo, 1998) had intermediate values. Because these variables have been shown to be rather homogeneous in ecologically and behaviorally dissimilar octodontoids, we assume that these slight differences are informative (Vieytes et al., 2007). These enamel traits of Ctenomys sp. 'perucho' could represent adaptive responses to biomechanical requirements, similar to those detected previously in the specialized fossil ctenomyid Eucelophorus (Vieytes et al., 2007) and other tooth-digging rodents (Geomyidae, Buzas-Stephens and Dalquest, 1991). Thus, although it was not possible to analyze the enamel pattern of incisors in all the species studied here, these differences suggest a trend of increasing tooth-digging specialization that agrees with our PC1. On the other hand, the second axis of variation (PC2) summarized scratch-digging specializations, which were not necessarily coupled with tooth-digging specializations (see Fig. 2).

Additionally, our results showed that morphological specialization patterns in Ctenomys were not influenced by size. This differs from previous proposals (Schleich and Vassallo, 2003; Vassallo and Mora, 2007) which indicate that cranial shape variation related to digging is constrained by size among Ctenomys species (see Verzi and Olivares, 2006; Verzi et al., 2010b). Regarding postcranial variables, although raw measurements showed moderate correlation with size, this was not the case for the indexes built to capture morphofunctional specialization.

The comparison of Ctenomys with other subterranean rodents shows some interesting parallels regarding patterns of specialization. In the subterranean pocket gophers (Geomyidae), which are particularly similar to tuco-tucos in general appearance (Reig et al., 1990), it has been hypothesized that increasing specialization for scratch- or tooth-digging would be alternative, so that a given taxon has stronger specializations at either craniodental or forelimb level, but not both (Lessa, 1993; Lessa and Stein, 1992, Fig. 3; Lessa and Thaeler, 1989). Among tuco tucos, some species follow this pattern, combining more specialized craniodental morphology with less specialized forelimbs (Fig. 2, quadrant IV: C. leucodon, Ctenomys sp. 'bellavista', Ctenomys sp. "perucho") and viceversa (Fig. 2, quadrant II: Ctenomys rionegrensis, Ctenomys sp. 'marmol'). However, at least some Ctenomys species exhibit strong specializations at both craniodental and forelimb level (Fig. 2, quadrant I: C. dorbignyi, C. lewisi, $C$. steinbachi) showing that these would have not been mutually exclusive in the evolution of the genus. Similar results were found in a recent analysis of the geomyid Thomomys (Marcy et al., 2016). It is not possible at present to assess the influence of phylogeny on this pattern because several of the taxa in our sample are undescribed populations that have not yet been included in phylogenetic analyses. Nevertheless, at least preliminarily, the distribution of taxa in the morphospace shows some degree of phylogenetic structure; when our results are inspected in light of the molecular results obtained by Parada et al. (2011), it becomes apparent that the species belonging to the 'mendocinus' group ( $C$. flamarioni, $C$. australis. $C$. azarae) are restricted to the portion of the morphospace that encompasses lesser craniodental specialization (Fig. 2, quadrants II and III); similarly, species belonging to the 'frater' group, i.e. C. lewisi and C. frater, show strong specialization at both craniodental and forelimb level (Fig. 2, quadrant I).

The fact that the species of our sample occupy all sectors of the morphospace suggests the evolution of diverse strategies for digging in Ctenomys from a threshold of specialization that would have already been acquired in the late Pliocene (Verzi et al., 2010a). Furthermore, the apparent lack of constraint in the specialization of tuco-tucos toward either or both digging modes might have played a role in the successful occupation of diverse environments, especially those most challenging, such as hard soils and/or with high proportion of roots and other elements that hinder burrow construction. Additional studies are necessary to explore the influence of phylogeny as well as relevant environmental characteristics on these patterns of morphological variation.

\section{Acknowledgements}

We thank J. Aparicio, M. Díaz, D. Flores, E. Lessa, J. Vargas Mattos for granting access to materials under their care; Walter Acosta and the staff at the X-ray facilities of Hospital Escuela Veterinario (FCV, UNLP). We thank two anonymous reviewers whose suggestions improved the manuscript. This research was supported by grants from Agencia Nacional de Promoción Científica y Tecnológica (PICT 2012-1150) and Universidad Nacional de La Plata (UNLP $11 / \mathrm{N} 822)$. 


\section{Appendix A. Supplementary data}

Supplementary data associated with this article can be found, in the online version, at http://dx.doi.org/10.1016/j.mambio.2017.07. 005.

\section{References}

Álvarez, A., Vieytes, E.C., Becerra, F., Olivares, A.I., Echeverría, A.I., Verzi, D.H Vassallo, A.I., 2015. Diversity of craniomandibular morphology in caviomorph rodents: an overview of macroevolutionary and functional patterns. In: Vassallo, A.I., Antenucci, D. (Eds.), Biology of Caviomorph Rodents: Diversity and Evolution. Sociedad Argentina para el Estudio de los Mamíferos, Buenos Aires, pp. 199-228

Becerra, F., Casinos, A., Vassallo, A.I., 2012. Biting performance and skull biomechanics of a chisel tooth digging rodent (Ctenomys tuconax; Caviomorpha; Octodontoidea). J. Exp. Zool. 9999A, 1-12.

Bidau, C.J., 1842. Family ctenomyidae lesson, 1842. In: Patton, J.L., Pardiñas, U.F.J., D'Elía, G. (Eds.), Mammals of South America. Rodents. University of Chicago Press, Chicago, pp. 818-877.

Borges, L.R., Maestri, R., Kubiak, B.B., Galiano, D., Fornel, R., Freitas, T.R.O., 2016. The role of soil features in shaping the bite force and related skull and mandible morphology in the subterranean rodents of genus Ctenomys (Hystricognathi: Ctenomyidae). J. Zool. 301, 108-117.

Boyde, A., Fortelius, M., 1986. Development, structure and function of rhinoceros enamel. Zool. J. Linn. Soc. 87, 181-214.

Buzas-Stephens, P., Dalquest, W.W., 1991. Enamel ultrastructure of incisor, premolars and molars in Thomomys, Cratogeomys, and Geomys (Rodentia, Geomyidae). Texas J. Sci. 43, 65-74.

Camin, S., Madoery, L., Roig, V., 1995. The burrowing behavior of Ctenomys mendocinus (Rodentia). Mammalia 59, 9-17.

Cock, A.G., 1966. Genetical aspects of metrical growth and form in animals. Q. Rev. Biol. 41, 131-190.

Cook, J.A., Lessa, E.P., Hadly, E.A., 2000. Paleontology, phylogenetic patterns and macroevolutionary processes in subterranean rodents. In: Lacey, A.E., Patton, J.L., Cameron, G.N. (Eds.), Life Underground. The Biology of Subterranean Rodents. The University of Chicago Press, Chicago, pp. 19-61.

De Santis, L.J.M., Moreira, G.J., Justo, E.R., 1998. Anatomía de la musculatura branquiomérica de algunas especies de Ctenomys Blainville 1826 (Rodentia, Ctenomyidae): caracteres adaptativos. Bol. Soc. Biol. Concepción Chile 69, 89-107.

Dubost, G., 1968. Les mammifères souterrains. Rev. d’Ecol. Biol. du sol. 5, 99-133.

Echeverría, A.I., Becerra, F., Vassallo, A.I., 2014. Postnatal ontogeny of limb proportions and functional indices in the subterranean rodent Ctenomys talarum (Rodentia: Ctenomyidae). J. Morph. 275, 902-913.

Elissamburu, A., Vizcaíno, S.F., 2004. Limb proportions and adaptations in caviomorph rodents (Rodentia: Caviomorpha). J. Zool. 262, 145-159.

Fernández, M.E., Vassallo, A.I., Zárate, M., 2000. Functional morphology and palaeobiology of the pliocene rodent Actenomys (Caviomorpha: Octodontidae): the evolution to a subterranean mode of life. Biol. J. Linn. Soc. 71, 71-90.

Flynn, L.J., Wahlert, J.H., 1978. SEM study of rodent incisors: preparation and viewing. Curator 21, 303-310.

Flynn, L.J., Nevo, E., Heth, G., 1987. Incisor enamel microstructure in blind mole rats: adaptive and phylogenetic significance. J. Mammal. 68, 500-507.

Freitas, T.R.O., 2016. Family ctenomyidae. In: Wilson, D.E., Lacher, T.E., Mittermeier, R.A. (Eds.), The Handbook of Mammals of the World. Lagomorphs and Rodents I. Lynx Edicions, Barcelona, pp. 498-534.

Giannoni, S.M., Borghi, C.E., Roig, V., 1996. The burrowing behavior of Ctenomys eremophilus (Rodentia: Ctenomyidae) in relation to substrate hardness. Mastozool. Neotrop. 3, 161-170.

Gomes Rodrigues, H., Šumbera, R., Hautier, L., 2016. Life in burrows channelled the morphological evolution of the skull in rodents: the case of African mole-rats (Bathyergidae, Rodentia). J. Mammal. Evol. 23, 175-189.

Gould, S.J., 1966. Allometry and size in ontogeny and phylogeny. Biol. Rev. 41, $587-638$

Hildebrand, M., 1985. Digging of quadrupeds. In: Hildebrand, M., Bramble, D.M., Liem, K.F., Wake, D.B. (Eds.), Functional Vertebrate Morphology. Belknap Press of Harvard University, Cambridge, pp. 90-108.

Honeycutt, R.L., Rowe, D.L., Gallardo, M.H., 2003. Molecular systematics of the South American caviomorph rodents: relationships among species and genera in the family Octodontidae. Mol. Phylog. Evol. 26, 476-489.

Hopkins, S.S.B., Davis, E.B., 2009. Quantitative morphological proxies for fossoriality in small mammals. J. Mamm. 90, 1449-1460.

Klingenberg, C.P., Zimmermann, M., 1992. Static, ontogenetic, and evolutionary allometry: a multivariate comparison in nine species of water striders. Am. Natural. 140, 601-620.

Koenigswald, W.v., Rensberger, J.M., Pfretzschner, H.U., 1987. Changes in the tooth enamel of early Paleocene mammals allowing increased diet diversity. Nature 328, 150-152.

Koenigswald, W.v., 1985. Evolutionary trends in the enamel of rodent incisors. In: Luckett, W.P., Hartenberger, J.L. (Eds.), Evolutionary Relationships Among Rodents: A Multidisciplinary Analysis. Plenum Press, New York, pp. 403-422.
Korvenkontio, V.A., 1934. Mikroskopische Untersuchungen an Nagerincisiven unter Hinweis auf die Schmelzstruktur der Backenzahne. Ann. Zool. Soc. Zool. Bot. Fenn.Vanamo 2, 1-274.

Lagaria, A., Youlatos, D., 2006. Anatomical correlates to scratch digging in the forelimb of European ground squirrels (Spermophilus citellus). J. Mammal. 87, $563-570$.

Lessa, E.P., 1990. Morphological evolution of subterranean mammals: integrating structural, functional, and ecological perspectives. In: Nevo, E., Reig, O.A. (Eds.), Evolution of Subterranean Mammals at the Organismal and Molecular Levels. Wiley-Liss, New York, pp. 211-230.

Lessa, E.P., 1993. Patrones de evolución morfológica en roedores subterráneos americanos. Bol. Soc. Zool. Uruguay 8, 37-46.

Lessa, E.P., Stein, B.R., 1992. Morphological constraints in the digging apparatus of pocket gophers (Mammalia: Geomyidae). Biol. J. Linn. Soc. 47, 439-453.

Lessa, E.P., Thaeler Jr., C.S., 1989. A reassessment of morphological specializations for digging in pocket gophers. J. Mammal. 70, 689-700.

Lessa, E.P., Vassallo, A.I., Verzi, D.H., Mora, M.S., 2008. Evolution of morphological adaptations for digging in living and extinct ctenomyid and octodontid rodents. Biol. J. Linn. Soc. 95, 267-283.

Marcy, A.E., Hadly, E.A., Sherratt, E., Garland, K., Weisbecker, V., 2016. Getting a head in hard soils: convergent skull evolution and divergent allometric patterns explain shape variation in a highly diverse genus of pocket gophers (Thomomys). BMC Evol. Biol. 16, 207.

Martin, T., 1999. Evolution of incisor enamel microstructure in Theridomyidae (Rodentia). J. Vert. Paleontol. 19, 550-565.

Mascheretti, S., Mirol, P.M., Giménez, M.D., Bidau, C.J., Contreras, J.R., Searle, J.B., 2001. Phylogenetics of the speciose and chromosomally variable rodent genus Ctenomys (Ctenomyidae, Octodontoidea), based on mitochondrial cytochrome b sequences. Biol. J. Linn. Soc. 70, 360-376.

McIntosh, A.F., Cox, P.G., 2016. The impact of digging on craniodental morphology and integration. J. Evol. Biol. 29, 2383-2394.

Mora, M., Olivares, A.I., Vassallo, A.I., 2003. Size, shape and structural versatility of the skull of the subterranean rodent Ctenomys (Rodentia, Caviomorpha): functional and morphological analysis. Biol. J. Linn. Soc. 78, 85-96.

Morgan, C.C., 2009a. Análisis de la diversidad morfológica vinculada a la capacidad fosorial en especies del género Ctenomys (Rodentia, Octodontidae). Universidad Nacional de La Plata, La Plata, PhD dissertation, Unpublished, 233 pp.

Morgan, C.C., 2009b. Geometric morphometrics of the scapula of South American caviomorph rodents (Rodentia: Hystricognathi): form, function and phylogeny. Mammal. Biol. 74, 497-506.

Morgan, C.C., 2015. The postcranial skeleton of caviomorphs: morphological diversity, adaptations and patterns. In: Vassallo, A.I., Antenucci, D. (Eds.), Biology of Caviomorph Rodents: Diversity and Evolution. Sociedad Argentina para el Estudio de los Mamíferos, Buenos Aires, pp. 167-198.

Morgan, C.C., Álvarez, A., 2013. The humerus of South American caviomorph rodents: shape, function and size in a phylogenetic context. J. Zool. 290, 107-116.

Morgan, C.C., Verzi, D.H., 2006. Morphological diversity of the humerus of the South American subterranean rodent Ctenomys (Rodentia, Ctenomyidae). J. Mammal. 87, 1252-1260.

Morgan, C.C., Verzi, D.H., 2011. Carpal- metacarpal specializations for burrowing in South American octodontoid rodents. J. Anat. 219, 167-175.

Nevo, E., 1979. Adaptive convergence and divergence of subterranean mammals. Ann. Rev. Ecol. Syst. 10, 269-308.

Nevo, E., 1999. Mosaic Evolution of Subterranean Mammals: Regression, Progression and Global Convergence. Oxford University Press, Oxford.

Parada, A., D’Elía, G., Bidau, C.J., Lessa, E.P., 2011. Species groups and the evolutionary diversification of tuco-tucos, genus Ctenomys (Rodentia: Ctenomyidae). J. Mammal. 92, 671-682.

Pfretzschner, H.U., 1988. Structural reinforcement and crack propagation in enamel. In: Russell, D.E., Santoro, J.P., Sigogneau-Russell, D. (Eds.), Teeth Revisited: Proceedings of the VIIth International Symposium on Dental Morphology. Mém. Mus. Hist. Nat. d’Hist. Nat. (série C), vol. 53, pp. 133-143.

Polly, P.D., 2007. Limbs in mammalian evolution. In: Hall, B.K. (Ed.), Fins into Limbs: Evolution, Development, and Transformation. University of Chicago Press, Chicago, pp. 245-268.

Quintana, C.A., 1994. Sistemática y anatomía funcional del roedor Ctenomyinae Praectenomys (Caviomorpha: Octodontidae) del Plioceno de Bolivia. Rev. Téc. YPFB 15, 175-185.

Reig, O.A., 1970. Ecological notes on the fossorial octodont rodent Spalacopus cyanus (Molina). J. Mammal. 51, 592-601.

Reig, O.A., Quintana, C.A., 1992. Fossil ctenomyine rodents of the genus Eucelophorus from the Pliocene and Early Pleistocene of Argentina (Caviomorpha: Octodontidae). Ameghiniana 29, 363-380.

Reig, O.A., Contreras, J.R., Piantanida, M.J., 1965. Estudio morfológico y estadístico en poblaciones del género Ctenomys dela provincia de Entre Ríos y de la zona costera bonaerense del Río de La Plata (Rodentia). Physis 25, 161-163.

Reig, O.A., Busch, C., Ortells, M.O., Contreras, J.R., 1990. An overview of evolution, systematics, molecular biology and speciation in Ctenomys. In: Nevo, E., Reig, O.A. (Eds.), Evolution of Subterranean Mammals at the Organismal and Molecular Levels. Wiley-Liss, New York, pp. 71-96.

Rensberger, J.M., 1997. Mechanical adaptation in enamel. In: Koenigswald, W.v., Sander, P.M. (Eds.), Tooth Enamel Microstructure. Balkema, Rotterdam, pp. 237-257. 
Rensberger, J.M., Koenigswald, W.v., 1980. Functional and phylogenetic interpretation of enamel microstructure in rhinoceroses. Paleobiology 6, 477-495.

Samuels, J.X., Van Valkenburgh, B., 2008. Skeletal indicators of locomotor adaptations in living and extinct rodents. J. Morphol. 269, 1387-1411.

Samuels, J.X., Van Valkenburgh, B., 2009. Craniodental adaptations for digging in extinct burrowing beavers. J. Vertebr. Paleontol. 29, 254-268.

Schafer, J.L., 1997. Analysis of Incomplete Multivariate Data. Chapman and Hall, New York.

Schleich, C.E., Vassallo, A.I., 2003. Bullar volume in subterranean and surface-dwelling caviomorph rodents. J. Mammal. 84, 185-189.

Stein, B.R., 2000. Morphology of subterranean rodents. In: Lacey, A.E., Patton, J.L., Cameron, G.N. (Eds.), Life Underground. The Biology of Subterranean Rodents. The University of Chicago Press, Chicago, pp. 19-61.

Steiner-Souza, F., de Freitas, T.R.O., Cordeiro-Estrela, P., 2010. Inferring adaptation within shape diversity of the humerus of subterranean rodent Ctenomys. Biol. J. Linn. Soc. 100, 353-367.

Ubilla, M., Altuna, C.A., 1990. Analyse de la morphologie de la main chez des espèces de Ctenomys de l'Uruguay (Rodentia: Octodontidae). Adaptations au fouissage et implications évolutives. Mammalia 54, 107-117.

Vassallo, A.I., 1998. Functional morphology, comparative behaviour, and adaptation in two sympatric subterranean rodent genus Ctenomys (Rodentia: Octodontidae). J. Zool. 244, 415-427.

Vassallo, A.I., Mora, M.S., 2007. Interspecific scaling and ontogenetic growth patterns of the skull in living and fossil ctenomyid and octodontid rodents (Caviomorpha: Octodontoidea). In: Kelt, D.A., Lessa, E.P., Salazar-Bravo, J.,
Patton, J.L. (Eds.), The Quintessential Naturalist: Honoring the Life and Legacy of Oliver P. Pearson, vol. 134. University of California Publications in Zoology, California, pp. 945-968.

Verzi, D.H., 2008. Phylogeny and adaptive diversity of rodents of the family Ctenomyidae (Caviomorpha): delimiting lineages and genera in the fossil record. J. Zool. 274, 386-394.

Verzi, D.H., Olivares, A.I., 2006. Craniomandibular joint in South American burrowing rodents (Ctenomyidae): adaptations and constraints related to a specialised mandibular position in digging. J. Zool. 270, 488-501.

Verzi, D.H., Olivares, A.I., Morgan, C.C., 2010a. The oldest South American tuco-tuco (late Pliocene, northwestern Argentina) and the boundaries of the genus Ctenomys (Rodentia, Ctenomyidae). Mammal. Biol. 75, 243-252.

Verzi, D.H., Âlvarez, A., Olivares, A.I., Morgan, C.C., Vassallo, A.I., 2010b. Ontogenetic trajectories of key morphofunctional cranial traits in South American subterranean ctenomyid rodents. J. Mammal. 91, 1508-1516.

Vieytes, E.C., Morgan, C.C., Verzi, D.H., 2007. Adaptive diversity of incisor enamel microstructure in South American burrowing rodents (family Ctenomyidae, Caviomorpha). J. Anat. 211, 296-302.

Wahlert, J.H., Koenigswald, W.v., 1985. Specialized enamel in incisors of eomyid rodents. Am. Mus. Nov. 2832, 1-12.

Warton, D.I., Wright, I.J., Falster, D.S., Westoby, M., 2006. Bivariate line-fitting methods for allometry. Biol. Rev. 81, 259-291.

Woods, C.A., Kilpatrick, C.W., 2005. Infraorder Hystricognathi Brandt, 1855. In: Wilson, D.E., Reeder, D.M. (Eds.), Mammal Species of the World. Johns Hopkins University Press, Baltimore, pp. 1538-1600. 